\title{
Influence of ozonised irrigation water on the morphological, bacterio- logical and sensory characteristics of 'Saint-Pierre' tomatoes grown in Algeria
}

\author{
Fouzia BENALI ${ }^{1,2}$, Nadia RAMDANI ${ }^{1}$
}

Received June 19, 2021; accepted September 25, 2021.

Delo je prispelo 19. junija 2021, sprejeto 25. septembra 2021

Influence of ozonised irrigation water on the morphological, bacteriological and sensory characteristics of 'Saint-Pierre' tomatoes grown in Algeria

Abstract: This article focuses on the study of the influence of ozonised water irrigation on the morphological, bacteriological and sensory characteristics of 'Saint-Pierre' tomatoes grown in Algeria. The results were compared with those irrigated with non-ozonised tap water called control of the same varietal type and grown under the same conditions. The work was carried out on seedlings of tomatoes grown and irrigated with ozonised water at different ozonisation times: 10 - seconds, 20 - seconds and 30-seconds, corresponding to lot I (tomato at 10-s), lot II (tomato at 20-s) and lot III (tomato at 30-s), respectively. Irrigation with ozonised water does not cause defects in shape, skin or colour of the fruits. They are, distinguished by a round shape, very red in colour, consistent and slightly acidic in taste. With good microbiological stability in accordance with the standard and good organoleptic quality except for the taste character of tomatoes at 30-seconds where a majority of evaluators estimated that 'they were bland and no big difference for the other criteria analysed. In general, our results showed that the ozonisation of irrigation water improves the growth, development, vigour and yield of tomato plants without altering the marketability of the fruits. This process encourages the use of ozonised water in agriculture since it has a high added value from an environmental and economic point of view and it can be generalized to other crops.

Key words: ozonised water; irrigation; 'Saint-Pierre' tomatoes; morphological; bacteriological and sensory characteristics
Vpliv ozonirane vode za namakanje na morfološke, bakteriološke in senzorične lastnosti paradižnika 'Saint-Pierre', rastočega v Alžiriji

Izvleček: Članek se osredotoča na vpliv ozoniranja vode za namakanje na morfološke, bakteriološke in senzorične lastnosti paradižnika 'Saint-Pierre' rastočega v Alžiriji. Rezultati so primerjani s tistimi, kjer je bila voda za namakanje iz vodovoda in ni bila ozonirana, kar je služilo kot kontrola, pri isti sorti paradižnika, gojenega v enakih razmerah. Sadike paradižnika za bile zalivane $\mathrm{z}$ vodo, ozonirano različno dolgo in sicer: $10 \mathrm{~s}$, $20 \mathrm{~s}$ in $30 \mathrm{~s}$, kar je ustrezalo naborom paradižnikov v poskusu: I (paradižnik pri 10 s), II (paradižnik pri 20 s) III (paradižnik pri $30 \mathrm{~s}$ ). Zalivanje $\mathrm{z}$ ozonirano vodo ni povzročilo poškodb v obliki, kožici in barvi plodov. Ti so bili značilno okrogle oblike, zelo rdeči, čvrsti in z rahlo kislim okusom. V primerjavi s standardom so imeli dobro mikrobiološko stabilnost in dobro organoleptično kakovost, razen okusa tistih, ki so bili zalivani z vodo ozonirano $30 \mathrm{~s}$, za katere je večina ocenjevalcev ocenila, da okus ni značilen, med ostalimi preučevanimi lastnostmi pa ni bilo velikih razlik. Na splošno so rezultati pokazali, da je ozoniranje vode za zalivanje izboljšalo rast, razvoj, vitalnost in pridelek paradižnika brez sprememb tržnih lastnosti plodov. Postopek vzpodbuja uporabo ozonirane vode v kmetijstvu, saj ima veliko dodano vrednost $\mathrm{z}$ vidika okolja in ekonomičnosti in bi se lahko splošno uporabljal tudi pri drugih kulturnih rastlinah.

Ključne besede: ozonirana voda; zalivanje; 'Saint-Pierre' paradižnik; morfološke, bakteriološke in senzorične lastnosti

1 Djillali Liabès University, Faculty of Exact Sciences, Department of Chemistry, Sidi Bel-Abbès, Algeria

2 Corresponding author, e-mail: fouzia.benali@univ-sba.dz 


\section{INTRODUCTION}

Tomato (Solanum lycopersicum L.) is one of the most consumed market garden crops in the world after potatoes (FAOSTAT, s. d.), of variable shape (spherical, oblong, elongated), and various colours (white, pink, red, yellow, orange, green, purple and black) depending on the variety (Joseph et al., 2017; Renaud, 2003). In general, tomato occupies an important place in the human diet; where it is consumed fresh, whole, dried, paste, puree, juice, sauce or tomato powder (Bhat et al., 2020; Nethaji et al., 2020; Siti Fadlilah et al., 2020). It is low in calories and very rich in water, vitamins, antioxidants and macrominerals such as iron, calcium, sulphur and potassium. It is rich in sugars (fructose and glucose), essential amino acids, organic acids and dietary fibres (Ali et al., 2020; García-Alonso et al., 2020). From the medicinal point of view, consumption of tomato fruits and their derivative products has been associated with the prevention of cardiovascular disease (Cámara et al., 2020; Cheng et al., 2017; Saini et al., 2020), several types of cancer (Rowles et al., 2018; Wu et al., 2021; Yang et al., 2013), as well as the maintenance of bone health (Walallawita et al., 2020). Tomato production is increasing over the years, where its annual production in Algeria rises from 107 million tonnes in 2014 to 148 million tonnes in 2019 (FAOSTAT, s. d.), cultivated across various regions of the country, in particular, wilayas of Tlemcen, Mostaganem, Ain-Defla, Chlef, Tipaza, Jijel, Skikda, Guelma, Annaba, Adrar and Biskra (Algerias Ministry of Agriculture and Rural Development, 2020). Plant diseases and pests affect tomato production, causing considerable yield drops and significant economic losses.

Ozone has been applied for irrigation water disinfection and to control nematodes that reduce crop yield of tomato (Guo et al., 2019; Landa Fernández et al., 2019). It is also used to residual pesticides decomposition following the overuse of chemicals in agricultural fields (Mitsugi et al., 2017). It is a multifunctional reagent; it breaks down quickly into oxygen without leaving any chemical residues, In addition to its toxicity against a wide range of microorganisms (Pandiselvam et al., 2017) it is advantageous for many other applications, such as purification and disinfection treatment of waste and drinking water, preservation and extension of food shelf life, sterilization of equipment, and elimination of unwanted aromas produced by bacteria during storage and shipping. It is also used to inactivate microorganisms on fresh produce, such as fruits, vegetables, meat, poultry, fish and eggs, and dry produce, like cereals, pulses and spices. It is used in the gaseous form to disinfect the air in cold rooms by removing ethylene to slow down the ripening process of fruits and vegetables without altering the quality charac- teristics, and in aqueous form using the ozonized water for washing food and ensure product safety (Horvitz \& Cantalejo, 2014; Pandiselvam et al., 2017).

The goal of our research is to study the influence of irrigation using ozonised water on tomato seedlings by varying the ozonisation times of water: 10 -seconds, 20 -seconds and 30-seconds while comparing the results with the control (tomato seedlings irrigated with tap water without ozonisation), in order to assess the effects of irrigation with ozonised water on the morphological, bacteriological and sensory characteristics of 'SaintPierre' tomatoes grown in Algeria. To the best of our knowledge this study has not been reported before, and it offers high added value for environmental, scientific and economic research fields.

\section{MATERIAL AND METHODS}

\subsection{EXPERIMENTAL DESIGN}

The study was carried out during the year 2020 in the north-western region of Algeria, exactly in the region of Oran, on tomato seedlings (seeds) of the same varietal type with the 'Saint-Pierre' appellation, of indeterminate growth. Sown in spring season in individual pots filled with potting soil, divided into four lots referenced as follows: lot I (tomato at 10-s); lot II (tomato at 20-s); lot III (tomato at 30-s) and finally lot IV (control tomato), where each lot contains five pots.

The irrigation water source used was tap water, then it was divided into four variants $A, B, C$ and $D$. The first three (A, B and C) were exposed to constant flows of gaseous ozone produced by ozone generator FM-C900 (BEYOK ozone, China), as shown in Figure1, during 10, 20 and 30-seconds, respectively. Variant D consists only of non-ozonised tap water as a control. The plants of batch I, II and III were then irrigated, regularly and respectively, with variants $A, B, C$ and subsequently compared with the control plants.

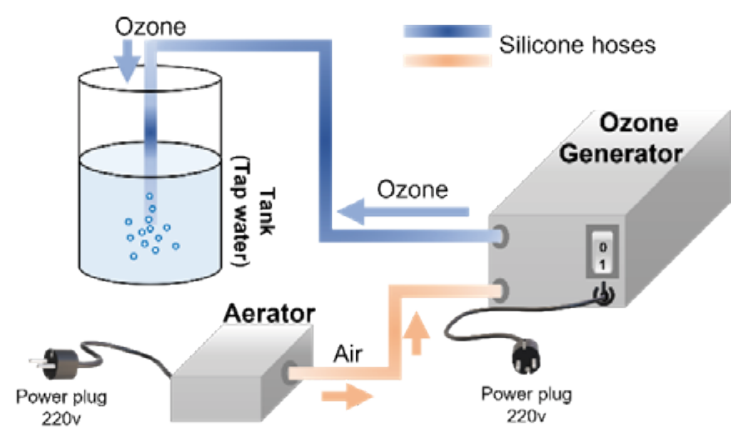

Figure 1: Schematic of the experimental setup 


\section{Temperature evolution during 2020, Region of Es Senia, Oran, Algeria}

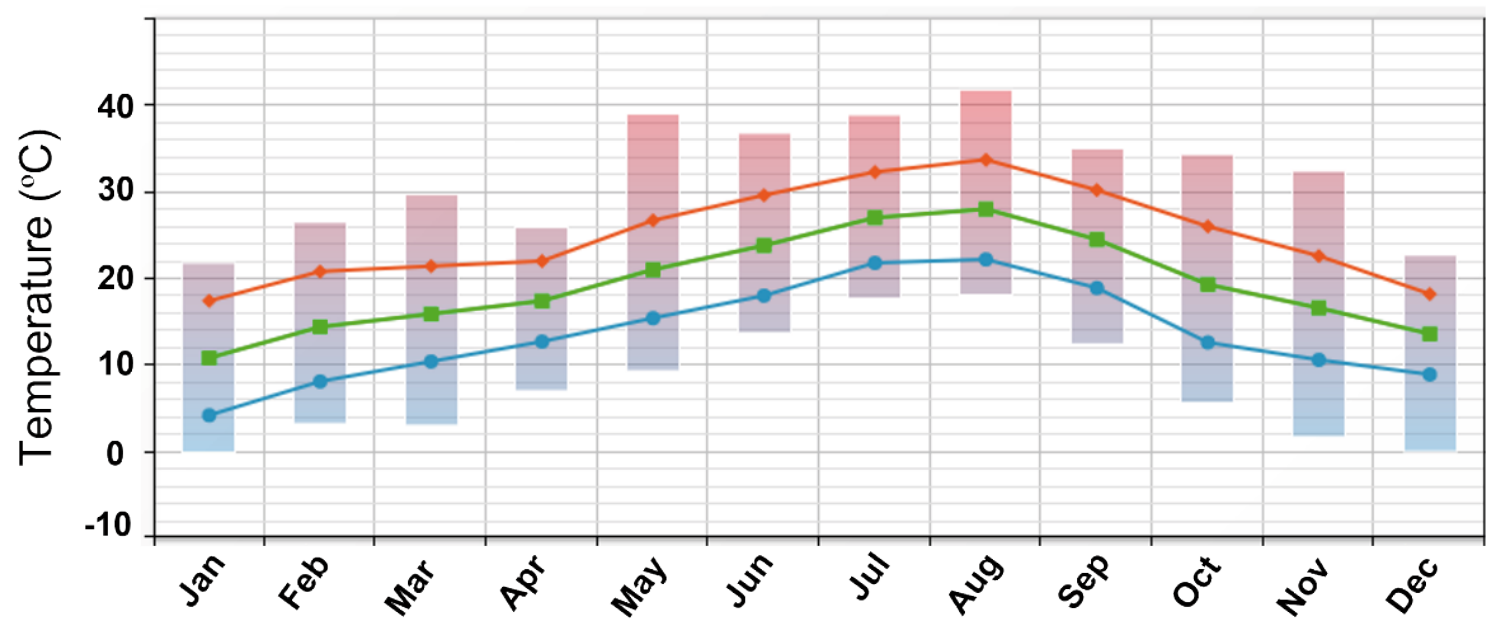

Extreme temperatures $=$ Minimum temperatures

Maximum temperatures

Average temperatures

Figure 2: Temperature evolution during the test period of the year 2020 (Nomades, s. d.)

After five weeks of cultivation, the seedlings are transplanted into large pots and staked, put outdoors, in a well-lit and sunny place. During the test period, the monthly average temperature was variable ranging from $20^{\circ} \mathrm{C}$ to $30^{\circ} \mathrm{C}$, see Figure 2, with an average monthly humidity ranging from $76 \%$ to $67 \%$ (Nomades, s. d.). The irrigation was performed regularly twice a week during the grow cycle.

\subsection{OZONE GENERATOR}

The cost, complexity, hazard potential, and generation of residual ozone were arguments that prevented investment in ozonation of irrigation water. The recent ozone generators have been manufactured with automated ozonation systems, more compact infrastructure, low cost and simplified maintenance which reduce investment and operating costs and makes renovations more feasible.

When operating an ozone water treatment system, the main concern in terms of failure is leakage in the ozone lines (feed gas and off gas). Serious ozone leaks represent a significant health hazard for farmers and crops, hence the integration of ozone gas sensors in all ozonation systems. A fail-safe system can represent a significant percentage of the overall cost but generally offers a moderate level of maintenance to ensure proper operation (Graham et al., 2011).

We should note that, it will be better for our future research to integrate ozone gas sensors into the ozona- tion system, in order to better control of any unexpected issues related to gas leakages.

\subsection{QUALITY ANALYSIS}

Fruit quality analyses were carried out with the aim of determining the morphological, bacteriological and organoleptic characteristics of each batch of tomatoes (I, II, III and IV). These analyses were carried out on samples of whole tomatoes, fresh, ripe, firm, healthy and of uniform red colour for the four batches, in order to evaluate the effects of ozonised water on the quality of the tomatoes by comparing them with the control samples.

\subsection{MORPHOLOGICAL ANALYSIS}

The analysis consists of determining the morphological characteristics of tomatoes by calculating the shape coefficient $\left(\mathrm{C}_{\mathrm{f}}\right)$, the number of cells $\left(\mathrm{N}_{\boldsymbol{e}}\right)$, the mass volume $(\rho)$ and the average fruit mass $\left(\mathrm{P}_{\mathbf{m}}\right)$ (Agassounon Djikpo Tchibozo et al., 2012).

The other physical parameters were determined using a calliper such as height and diameter. These analyses make it possible to identify and characterize the variety of the tomato studied.

The shape coefficient is given by the following equation:

$$
C_{f}=\frac{\text { Average fruit height }}{\text { Average fruit diameter }}
$$


It allows varieties to be classified into three categories:

$\mathrm{C}_{\mathrm{f}}<0.8$ : it is a flattened shape;

$\mathrm{C}_{\mathrm{f}}>1$ : it is an elongated shape;

$0.8<\mathrm{C}_{\mathrm{f}}<1$ : it is a round shape.

\subsection{MICROBIOLOGICAL ANALYSIS}

The purposes of these analyses were to assess the microbiological quality of the four batches of tomatoes (I, II, III and IV). They allow checking the possible presence or the absence of microorganisms in the samples to be analysed which is summarized in the search and the enumeration of the total coliforms and the faecal coliforms according to the standard ISO 7251:2005, as well as the determined yeasts and moulds by the ISO 21527 1:2008 method. A quantity of $10 \pm 2 \mathrm{~g}$ of each sample of tomatoes was weighed and added to $90 \mathrm{ml}$ of Ringer's solution, each placed in sterile sachets, crushed and homogenized in the Stomacher, thus constituting the stock solution.

The analysis was carried out by seeding the stock suspension of $1 \mathrm{ml}$ aliquots and its $10^{-1}, 10^{-2}$ and $10^{-3}$ decimal dilutions on suitable culture media and under aseptic conditions.

Yeasts and moulds testify to the appearance of phenomena of deterioration of tomatoes, discoloration and modification of the flavour, on the other hand the presence of total coliforms and faecal coliforms reflect the hygienic level of the fruits. Table 1 groups the culture media used.

\subsection{APPRAISAL OF SENSORY CHARACTERISTICS}

The objective of this analysis is, first to evaluate the organoleptic characteristics of the experimental and control tomatoes according the parameters of standard ISO 5492: 2008 which is summarized in: the appearance, colour, consistency, smell, acidity, aroma and taste. Second, rank the tomato samples offered for tasting noting their acceptability or their preferences over each other.

The evaluation was carried out on fresh, mature, healthy, firm and red tomatoes by a panel of tasters. Tomato samples and pre-established questionnaires were distributed to each taster who agreed to collaborate in the study and no information was provided on the different batches of tomatoes in order to objectively assess the perceived sensory characteristics.

\subsection{UNCERTAINTIES AND SHORTCOMINGS}

It should be noted that our seedlings have been placed in outdoor conditions, while greenhouse and commercial conditions are to be expected in our future research in order to collect additional information such as gas exchange parameters and economic feasibility. Soil analyses before and after treatment with ozonised water will be recommended to assess any impact that could modify the quality of the latter. In addition, irrigation with aqueous ozone at 30-seconds gave a better yield but the tomatoes are of lower taste quality, this concentration should be taken into account and should be considered as a threshold value and study the possibility of improving the sensory qualities of fruits.

Finally, increasing the number of panel of tasters will lead to a better appraisal of the organoleptic characteristics.

\section{RESULTS AND DISCUSSION}

\subsection{MORPHOLOGICAL CHARACTERISTICS OF THE TOMATOES STUDIED}

The four lots of tomatoes studied are distinguished by smooth-looking fruits, of a pronounced red colour, strongly lobed (6 to 8 lobes) and round $\left(C_{f}>0.8\right)$. The width of the fruits for the four lots is slightly more extended, which gives it the appearance of a large fruit, the height, the diameters and the average mass of the fruits are variable (Figure 3 ).

The highest average mass was observed in the tomato at 30-s, followed by the tomato at 20-s then the tomato at 10 -s and finally the control tomato with $81 \mathrm{~g}, 77 \mathrm{~g}, 72 \mathrm{~g}$ and $63 \mathrm{~g}$ respectively; the same for the density which is $0.97 \mathrm{~g} \mathrm{~cm}^{-3}, 0.94 \mathrm{~g} \mathrm{~cm}^{-3}, 0.93 \mathrm{~g} \mathrm{~cm}^{-3}$ for the tomatoes at 30 s, 20 -s and 10 -s and $0.91 \mathrm{~g} \mathrm{~cm}^{-3}$ for the control tomatoes. (Table 2).

The tomatoes responded differently despite the same growing conditions and the same varietal type, the highest number of tomatoes picked during the whole period of the trial was observed in the tomatoes at 30-s with $31.86 \%$ followed by the tomatoes at 20 -s with $28.32 \%$ then the tomatoes at 10 -s with $22.12 \%$ and finally $17.70 \%$ for the control tomatoes.

The difference in the quantity of tomatoes picked for the three lots (I, II, III) is proportional to the concentration of the ozonised water.

In July, the batches (I, II, III) show an early harvest in relation to the control batch. (Figure 4).

During the hottest months the four lots recorded a large number of tomatoes picked with different quanti- 
Table 1: The culture media used for the enumeration and the quantitative enumeration of the germs investigated in the tomatoes studied

\begin{tabular}{llll}
\hline Designation & Culture centre & Cultivation conditions & Norm \\
\hline Total coliforms & VRBL Agar (Violet Red Bile Lactose & Incubation $: 37{ }^{\circ} \mathrm{C}$ for $24 \pm 2 \mathrm{~h}$ & ISO $7251: 2005$ \\
& Agar). & & \\
Faecal coliforms & VRBL Agar (Violet Red Bile Lactose & Incubation $: 44^{\circ} \mathrm{C}$ for $24 / 48 \pm$ & ISO $7251: 2005$ \\
& Agar). & $2 \mathrm{~h}$ & \\
Yeasts and moulds & DRBC Agar (Dichloran-rose & $\begin{array}{l}\text { Incubation }: 25^{\circ} \mathrm{C} \pm 1{ }^{\circ} \mathrm{C} \text { for } 5 \\
\text { days }\end{array}$ & ISO 21527-1:2008 \\
& bengalchloramphènicol) & days & \\
\hline
\end{tabular}

ties and as the seasons progressed the quantities of fruit picked decreased.

The largest quantities of the picked tomatoes were recorded during the month of August for the four lots. (Figure 4).

Tomatoes at 30-s were among the best performing tomatoes compared to other lots in terms of production density, average mass and density (Figure 3 ) and (Table 2).

No defect in development, shape, epidermis or colouring was observed in comparison with the control tomatoes, total absence on all the samples studied of

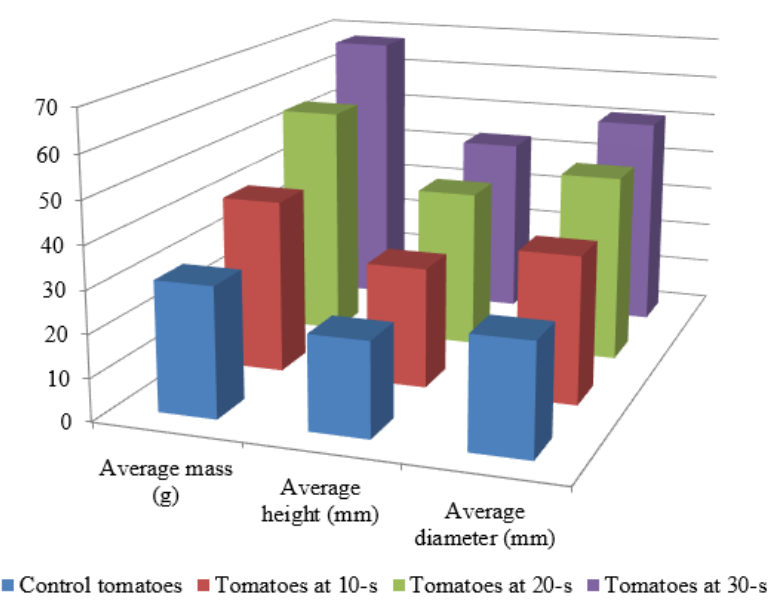

Figure 3: The average values of mass, height and diameter of experimental and control tomatoes protuberance or crevice and no presence of corky bruising of umbilical form or elongated epistolary scar. These fruits have good resistance to cracking, a very developed placenta and a large number of seeds. Table 2 shows the main morphological characteristics of the four batches of tomatoes at 10-s, 20-s, 30-s and control.

\subsection{RESULTS OF MICROBIOLOGICAL ANALYSIS}

The results obtained for the enumeration of total and faecal coliforms as well as for the quantitative enumeration of yeasts and moulds, show a total absence of all the germs sought both for tomatoes irrigated with ozonised water as for control tomatoes, while the standard tolerates $10^{3} \mathrm{cfu} \mathrm{g}^{-1}$ for total coliforms, which means that the samples studied show stability and a good hygienic level. This coincides with the work of (Heß \& Gallert, 2015; (Güzel-Seydim et al., 2004) where ozone has been used as an antimicrobial agent on a variety of pathogenic organisms, such as strains Escherichia coli, Enterococcus, Staphylococcus, fungi and viruses on the other hand (Guo \& Wang, 2017) reveal that $E$. coli treated with moderate concentrations of ozonised water $\left(0.5 \mathrm{mg} \mathrm{l}^{-1}\right.$ ozone at 28 ${ }^{\circ} \mathrm{C}$ ) were completely inactivated. Irrigation with ozonised water has no harmful influence on the experimental tomatoes compared to the control tomatoes and the results obtained show compliance with the standard (Inter ministerial decree, Official Journal No. 39, 2017). These tomatoes pose no health risk, and have good marketability. These results are shown in Table 3.

Table 2: Morphological characteristics of experimental and control tomatoes

\begin{tabular}{lllllll}
\hline & $\begin{array}{l}\text { Coefficient } \\
\text { of form } \mathrm{C}_{\mathrm{f}}\end{array}$ & $\begin{array}{l}\text { Number of } \\
\text { lobes } \mathrm{N}_{\ell}\end{array}$ & $\begin{array}{l}\text { Average } \\
\text { fruit mass } \\
\mathrm{P}_{\mathrm{m}}(\mathrm{g})\end{array}$ & $\begin{array}{l}\text { Volumic mass } \\
\text { in } \rho\left(\mathrm{g} \mathrm{cm}^{-3}\right)\end{array}$ & $\begin{array}{l}\text { Protuberance } \\
\text { crevasse, } \\
\text { Green collar }\end{array}$ & $\begin{array}{l}\text { Seeds } \\
\text { number }\end{array}$ \\
\hline Tomato at 10-s & 0.83 & $6-8$ & 72.27 & 0.93 & absence & $>200$ \\
Tomato at 20-s & 0.84 & $6-8$ & 77.18 & 0.94 & absence & $>200$ \\
Tomato at 30-s & 0.85 & $6-8$ & 80.87 & 0.97 & absence & absence \\
Control tomato & 0.81 & $6-8$ & 63.22 & 0.91 & ance & 200 \\
\hline
\end{tabular}




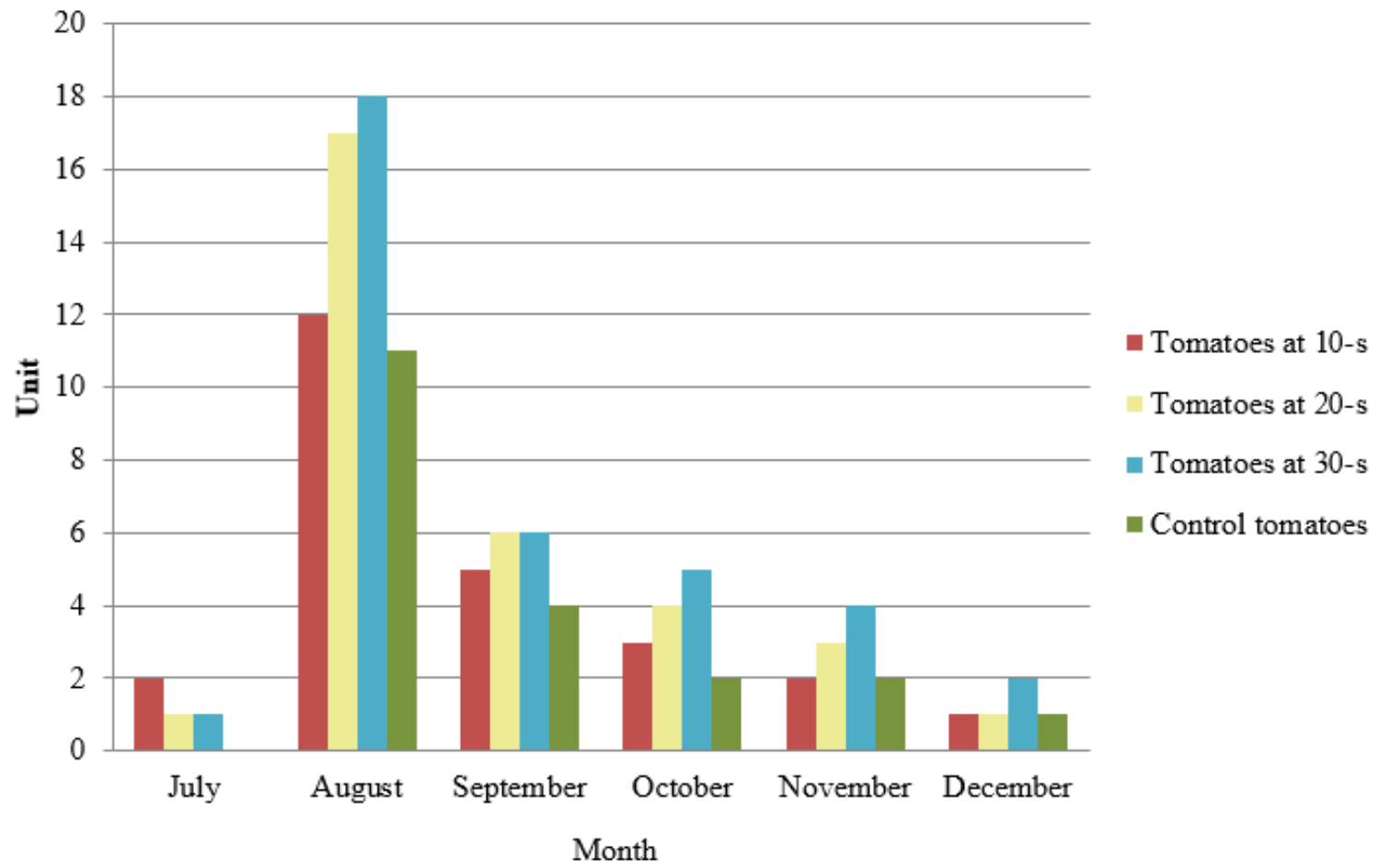

Figure 4: The number of tomatoes picked of the four lots during the test period

\subsection{SENSORY CHARACTERISTICS OF TOMATOES}

The test was carried out by a panel of tasters composed of twelve (12) people, men and women aged 27 to 58 years. It made it possible to evaluate the organoleptic qualities of the experimental tomatoes compared to the control tomatoes. The criteria used are colour (very red to red), taste (salty, sweet), acidity, consistency, texture (melting, crunchy and floury), aroma and odour.

The sensory assessment was carried out on freshly harvested tomatoes for the four lots (I, II, III and IV). It emerges that twelve of the evaluators find that the three experimental batches are very red, identical to the controls. Recalling that colour of the fruit is linked to the abundant content of carotenoids in the peel and flesh of the fruit. As for the taste, the tomatoes at 10-s, 20-s and the control tomatoes were judged to be lightly salted by eight of the tasters, while for the tomatoes at 30-s the assessment is in favour of bland with seven evaluators (Table $4 \mathrm{~b}$ ). On the other hand, eight people believed that the four batches of tomatoes were not very acidic while one taster did not find them at all acidic. The other most sought-after criterion is the scent character, nine of the evaluators believed that tomatoes had a strong odour, qualified as a strong tomato odour to little pronounced. The consistency of tomato fruits is also an important quality criterion as appreciated as the colour and the taste; it determines the resistance of the fruits to handling and their behaviour in the marketing circuit. The firmness was estimated manually, and ten evaluators considered the four lots of tomatoes to be very firm to firm, while one taster felt they were not very firm (Table 4a).

In order to assess (the salinity, acidity, sweetness,

Table 3: Bacteriological characteristics of tomatoes irrigated with ozonised water and controls

\begin{tabular}{|c|c|c|c|c|c|c|}
\hline \multirow[b]{2}{*}{ Designation } & \multicolumn{3}{|l|}{ E. coli } & \multicolumn{3}{|c|}{ Yeasts and moulds } \\
\hline & $10^{-1}$ & $10^{-2}$ & $10^{-3}$ & $10^{-1}$ & $10^{-2}$ & $10^{-3}$ \\
\hline Tomato at $10-\mathrm{s}$ & absence & absence & absence & absence & absence & absence \\
\hline Tomato at 20-s & absence & absence & absence & absence & absence & absence \\
\hline Tomato at 30-s & absence & absence & absence & absence & absence & absence \\
\hline Control tomato & absence & absence & absence & absence & absence & absence \\
\hline
\end{tabular}


juiciness), and to translate the more or less intense characteristics of each of the criteria, we use the evaluation of the hedonic quality of the four batches (I, II, III, IV) tomatoes.

The results show that all the lots show tomatoes of red colour, of round shapes, smooth and shiny, fleshy, tender, slightly acidic and less salty, of firm and tasty flesh, of easily removable cuticle.

As a result, irrigating with ozonised water has no significant effect on the perception of the organoleptic characteristics of tomatoes compared to controls except for the taste character of tomatoes at 30-s where seven people of the panel estimated that 'they were bland and there is no difference for the other criteria.

The panellists' results were reported in Table $4(\mathrm{a}, \mathrm{b})$.

\subsection{COMPARATIVE ANALYSIS}

In our study, the agronomic characteristics of tomatoes irrigated with ozonised water such as seedling development, early germination, growth, vigour, plant size and yield were greater compared to control plants. Which is consistent with the work of Martínez-Sánchez \& Aguayo(2019) where irrigation with aqueous ozone improved the development of greenhouse-grown pepper seedlings and the microbiological quality of the water.
The plants developed a higher number of leaves and secondary roots, which could improve the adaptability and yield of the seedlings when transplanted into the fields. Studies by Ohashi-Kaneko et al. (2009) reported that treatment with ozonised water improves root respiration and increases nutrient uptake and biomass production.

The yield of the experimental tomatoes (10-s, 20-s and 30-s) was significantly higher than in the control plants. Guo \& Wang (2017) reported that direct spraying of ozonised water on growing crops in fields increases their antioxidant content and photosynthetic activity, which enhances crop protection and prevents infection with plant pathogens. Plants subjected to ozonised water treatments below $10 \mathrm{mg} \mathrm{l}^{-1}$ had slightly increased plant diameter and height. The fresh mass of the leaf treated with $6 \mathrm{mg} \mathrm{l}^{-1}$ of ozonised water was remarkably increased by $40.6 \%$ compared to the control. Rozpądek et al. (2015) reported that plants subjected to aqueous ozone treatments during vegetation showed accelerated growth and reached marketable quality more quickly.

The effects of irrigation of tomatoes with ozonised water at 10-s, 20-s and 30-s showed no morphological damage compared to the control, this is supported by the work of Guo \& Wang (2017) reporting that no negative effects were observed after treatment with ozonised water spray at concentrations below $8 \mathrm{mg} \mathrm{l}^{-1}$ carried out on Chinese cabbage, on the other hand, visible damage to

Table 4a: Summarizes sensoria's parameters of the four batches of the tomatoes as perceived by the tasters

\begin{tabular}{|c|c|c|c|c|c|c|c|}
\hline \multicolumn{8}{|c|}{ Sensory parameters of the four batches of tomatoes (I, II, III, IV) } \\
\hline Colour & & Acidity & & Consistency & & Aroma and odour & \\
\hline Level & $\begin{array}{l}\text { Tasters } \\
\text { number }\end{array}$ & Level & $\begin{array}{l}\text { Tasters } \\
\text { number }\end{array}$ & Level & $\begin{array}{l}\text { Tasters } \\
\text { number }\end{array}$ & Level & $\begin{array}{l}\text { Tasters } \\
\text { number }\end{array}$ \\
\hline Very red & 12 & Very acidic & 0 & Very consistent & 1 & Very pronounced & 0 \\
\hline Red & 0 & Acid & 1 & Consistent & 9 & Pronounced & 3 \\
\hline Less red & 0 & Less acidic & 8 & Less consistent & 1 & Less pronounced & 6 \\
\hline Not red & 0 & Not at all acidic & 1 & Not consistent & 0 & Not pronounced & 1 \\
\hline Indifferent & 0 & Indifferent & 2 & Indifferent & 1 & Indifferent & 2 \\
\hline
\end{tabular}

Table 4b: Summarizes sensoria's parameters of the four batches of the tomatoes as perceived by the tasters

\begin{tabular}{lllr}
\hline Other flavour Tomatoes at $10-\mathrm{s}, 20$-s and controls & \multicolumn{2}{l}{ Other flavour for the tomatoes at 30-s } \\
\hline Level & Tasters number & Level & Tasters number \\
\hline Very salty & 0 & Very salty & 0 \\
Salty & 1 & Salty & 1 \\
Slightly salty & 8 & Slightly salty & 1 \\
Not at all salty & 1 & Not at all salty & 2 \\
Fade & 0 & Fade & 7 \\
Indifferent & 2 & Indifferent & 1 \\
\hline
\end{tabular}


the leaves was observed after the plants were exposed to $10 \mathrm{mg} \mathrm{l}^{-1}$ of ozonised water spray for 15 days during the reproductive phase of the plants.

Aqueous ozone is a germination activator in limited quantities; excessive doses may affect the quality of the seeds. These results vary according to the varieties of species in question (Pandiselvam et al., 2020).

An additional positive effect of ozonisation is the inactivation of pathogenic bacteria, such as Escherichia coli, Enterococcus and Staphylococcus strains (Heß \& Gallert, 2015) which raise crop protection and prevents infection with plant pathogens, It is also used to disinfect irrigation water and as an alternative to pesticides (Guo et al., 2019; Landa Fernández et al., 2019).

Finally, as future research, we can consider the irrigation with ozonised water at different concentrations at a large scale either in greenhouse or in open fields. Determining the threshold values of aqueous ozone concentrations that can be applied into the different parts of the plants and at all growth stages, and duration and frequency of irrigation beyond which damage could occur affecting crops would be interesting to be investigated.

The effect of ozonised water spraying onto the tomato fruits and leaves could also be taken into account for the rest of our work.

\section{CONCLUSION}

The objective of this work was the experimental study of the effect of irrigation with ozonised water on the morphological, bacteriological and sensory characteristics of 'Saint-Pierre' tomatoes grown in Algeria. On the basis of our study and taking into consideration all the observations on the experimental part, the results of the analysis reveal that the experimental fruits do not present any defect in development, shape, skin or colouring, all the batches show satisfactory firmness with good resistance to cracking. These characteristics constitute an advantage in the marketing of tomatoes; moreover, the latter have a good hygienic level, and present no health risk for consumers.

The greater quantities of tomatoes picked as well as the size of the fruit is proportional to the concentration of the ozonized water. This observation proves the positive influence of irrigation with ozonised water as well as the different concentrations of ozone on the tomato plants. Despite this, seven tasters felt that 30-s tomatoes tasted bland unlike other lot I and II. The yield of 20-s tomatoes was lower than that of tomatoes at 30-s but with better taste quality than the latter. Therefore, this concentration is highly recommended for cultivation under the climatic conditions of the study region.
Irrigation with ozonised water can be used to increase the yield without negative impact on the environment and the quality of the product, moreover the ozonised water generator does not require large investments, nor specific infrastructure of low energy consumption and maintenance, it is easy to use, which means that it can be implemented anywhere.

However, studies must be continued for a better application of this technique in other growing conditions and on different varietal types or other market garden products. We have carried out this research on a small number of samples and on a single varietal type; we plan in the future to repeat this study on different plant species and to study them on a larger number of specimens.

Our study will serve as a basis for introducing ozonised water into crop irrigation in the region of Oran (Western Mediterranean region) to increase yield, size and to accelerate germination, flowering and tomatoes fruit production. As perspectives, similar studies must be carried out in other regions of Algeria such as the Tellian, arid, semi-arid, Atlas and Saharan regions and determining the impact of different concentrations of aqueous ozone on the characteristics agronomic, morphological, physicochemical, bacteriological, organoleptic and nutritional, for a better understanding of the climate effect in parallel to the application of ozonised water at the large scale. A soil analysis would also be recommended for tomatoes produced with an environmentally friendly process.

\section{REFERENCES}

Agassounon Djikpo Tchibozo, M., Gomez, S., Tchobo, F., Soumanou, M., \& Toukourou, F. (2012). Essai de conservation de la tomate par la technique de la déshydratation imprégnation par immersion (DII). International Journal of Biological and Chemical Sciences, 6(2), 657-669. https://doi. org/10.4314/ijbcs.v6i2.10

Ali, M. Y., Sina, A. A. I., Khandker, S. S., Neesa, L., Tanvir, E. M., Kabir, A., Khalil, M. I., \& Gan, S. H. (2020). Nutritional composition and bioactive compounds in tomatoes and their impact on human health and disease : A review. Foods, 10(1), 45. https://doi.org/10.3390/foods10010045

Bhat, N. A., Wani, I. A., \& Hamdani, A. M. (2020). Tomato powder and crude lycopene as a source of natural antioxidants in whole wheat flour cookies. Heliyon, 6(1), e03042. https://doi.org/10.1016/j.heliyon.2019.e03042

Cámara, M., Fernández-Ruiz, V., Sánchez-Mata, M.-C., Díaz, L. D., Kardinaal, A., \& Lieshout, M. van. (2020). Evidence of antiplatelet aggregation effects from the consumption of tomato products, according to EFSA health claim requirements. Critical Reviews in Food Science and Nutrition, 60(9), 1515-1522. https://doi.org/10.1080/10408398.2019.1 577215 
Cheng, H. M., Koutsidis, G., Lodge, J. K., Ashor, A., Siervo, M., \& Lara, J. (2017). Tomato and lycopene supplementation and cardiovascular risk factors: A systematic review and meta-analysis. Atherosclerosis, 257, 100-108. https://doi. org/10.1016/j.atherosclerosis.2017.01.009

FAOSTAT. (s. d.). Consulté 28 mai 2021, à l'adresse http://www. fao.org/faostat/fr/\#compare

García-Alonso, F.-J., García-Valverde, V., Navarro-González, I., Martín-Pozuelo, G., González-Barrio, R., \& Periago, M. J. (2020). Tomato. In Nutritional Composition and Antioxidant Properties of Fruits and Vegetables (p. 255-271). Elsevier. https://doi.org/10.1016/B978-0-12-812780-3.00015-5

Graham, T., Zhang, P., Woyzbun, E., \& Dixon, M. (2011). Response of hydroponic tomato to daily applications of aqueous ozone via drip irrigation. Scientia Horticulturae, 129(3), 464-471. https://doi.org/10.1016/j.scienta.2011.04.019

Guo, Z., \& Wang, Q. (2017). Efficacy of ozonated water against Erwinia carotovora subsp. carotovora in Brassica campestris ssp. chinensis. Ozone: Science \& Engineering, 39(2), 127-136. https://doi.org/10.1080/01919512.2016.1270744

Guo, Z., Wang, Z., Li, Y., \& Wang, Q. (2019). Effect of different concentrations of ozone on in vitro plant pathogens development, tomato yield and quality, photosynthetic activity and enzymatic activities. Ozone: Science \& Engineering, 41(6), 531-540. https://doi.org/10.1080/01919512.2019.159 1268

Güzel-Seydim, Z., Bever Jr, P. I., \& Greene, A. K. (2004). Efficacy of ozone to reduce bacterial populations in the presence of food components. Food Microbiology, 21(4), 475-479. https://doi.org/10.1016/j.fm.2003.10.001

Heß, S., \& Gallert, C. (2015). Sensitivity of antibiotic resistant and antibiotic susceptible Escherichia coli, Enterococcus and Staphylococcus strains against ozone. Journal of water and health, 13(4), 1020-1028. https://doi.org/10.2166/ wh.2015.291

Horvitz, S., \& Cantalejo, M. (2014). Application of ozone for the postharvest treatment of fruits and vegetables. Critical reviews in food science and nutrition, 54(3), 312-339. https://doi.org/10.1080/10408398.2011.584353

Inter ministerial decree, Official Journal39. (2017, juillet 2). JOURNAL OFFICIEL DE LA REPUBLIQUE ALGERIENNE DEMOCRATIQUE ET POPULAIRE. https://www.joradp. dz/FTP/JO-FRANCAIS/2017/F2017007.pdf

Joseph, H., Nink, E., McCarthy, A., Messer, E., \& Cash, S. B. (2017). "The Heirloom tomato is 'In'. Does it matter how it tastes?” Food, Culture \& Society, 20(2), 257-280. https://doi. org/10.1080/15528014.2017.1305828

Landa Fernández, I. A., Monje-Ramirez, I., \& Orta Ledesma de Velásquez, M. T. (2019). Tomato crop improvement using ozone disinfection of irrigation water. Ozone: Science \& Engineering, 41(5), 398-403. https://doi.org/10.1080/0191951 2.2018.1549474

Martínez-Sánchez, A., \& Aguayo, E. (2019). Effect of irrigation with ozonated water on the quality of capsicum seedlings grown in the nursery. Agricultural Water Management, 221, 547-555. https://doi.org/10.1016/j.agwat.2019.05.027

Mitsugi, F., Abiru, T., Ikegami, T., Ebihara, K., \& Nagahama, K. (2017). Treatment of nematode in soil using surface barrier discharge ozone generator. IEEE Transactions on
Plasma Science, 45(12), 3076-3081. https://doi.org/10.1109/ TPS.2017.2708706

Nethaji, D. K., Suresh, S., Prasanna, J. E. H., Vijayagopal, V., \& Ramesh, G. (2020). Development of mango and tomato paste and it's physico-chemical characterization. International Journal of Scientific Research in Science, Engineering and Technology, 165-171. https://doi.org/10.32628/ IJSRST207537

Nomades, D. C. (s. d.). Météo en Algérie en 2020. Historique Météo. Consulté 19 juin 2021, à l'adresse https://www.historique-meteo.net/afrique/algerie/2020/

Ohashi-Kaneko, K., Yoshii, M., Isobe, T., Park, J.-S., Kurata, K., \& Fujiwara, K. (2009). Nutrient solution prepared with ozonated water does not damage early growth of hydroponically grown tomatoes. Ozone: Science \& Engineering, 31(1), 21-27. https://doi.org/10.1080/01919510802587523

Pandiselvam, R., Mayookha, V. P., Kothakota, A., Sharmila, L., Ramesh, S. V., Bharathi, C. P., Gomathy, K., \& Srikanth, V. (2020). Impact of ozone treatment on seed germination A systematic review. Ozone: Science \& Engineering, 42(4), 331-346. https://doi.org/10.1080/01919512.2019.1673697

Pandiselvam, R., Sunoj, S., Manikantan, M. R., Kothakota, A., \& Hebbar, K. B. (2017). Application and kinetics of ozone in food preservation. Ozone: Science \& Engineering, 39(2), 115-126. https://doi.org/10.1080/01919512.2016.1268947

Renaud, V. (2003). Tomate. Tous les legumes courants, rares ou méconnus cultivables sous nos climats. Ulmer. Paris, Ulmer, 135-137.

Rowles, J. L., Ranard, K. M., Applegate, C. C., Jeon, S., An, R., \& Erdman, J. W. (2018). Processed and raw tomato consumption and risk of prostate cancer: A systematic review and dose-response meta-analysis. Prostate Cancer and Prostatic Diseases, 21(3), 319-336. https://doi.org/10.1038/s41391017-0005-X

Rozpądek, P., Nosek, M., Ślesak, I., Kunicki, E., Dziurka, M., \& Miszalski, Z. (2015). Ozone fumigation increases the abundance of nutrients in Brassica vegetables : Broccoli (Brassica oleracea var. italica) and Chinese cabbage (Brassica pekinensis). European Food Research and Technology, 240(2), 459-462. https://doi.org/10.1007/s00217-014-2372-Z

Saini, R. K., Rengasamy, K. R. R., Mahomoodally, F. M., \& Keum, Y.-S. (2020). Protective effects of lycopene in cancer, cardiovascular, and neurodegenerative diseases : An update on epidemiological and mechanistic perspectives. Pharmacological Research, 155, 104730. https://doi.org/10.1016/j. phrs.2020.104730

Siti Fadlilah, Adi Sucipto, \& Mohamad Judha. (2020). Cucumber (Cucumis sativus) and tomato (Solanum lycopersicum) juice effective to reduce blood pressure. GSC Biological and Pharmaceutical Sciences, 10(1), 001-007. https://doi. org/10.30574/gscbps.2020.10.1.0246

Walallawita, U. S., Wolber, F. M., Ziv-Gal, A., Kruger, M. C., \& Heyes, J. A. (2020). Potential role of lycopene in the prevention of postmenopausal bone loss : Evidence from molecular to clinical studies. International Journal of Molecular Sciences, 21(19), 7119. https://doi.org/10.3390/ijms21197119

Wu, H., Li, W., Wang, T., Rong, Y., He, Z., Huang, S., Zhang, L., Wu, Z., \& Liu, C. (2021). a-tomatine, a novel early-stage autophagy inhibitor, inhibits autophagy to enhance apoptosis 
via Beclin-1 in Skov3 cells. Fitoterapia, 152, 104911. https:// doi.org/10.1016/j.fitote.2021.104911

Yang, T., Yang, X., Wang, X., Wang, Y., \& Song, Z. (2013). The role of tomato products and lycopene in the preven- tion of gastric cancer: A meta-analysis of epidemiologic studies. Medical Hypotheses, 80(4), 383-388. https://doi. org/10.1016/j.mehy.2013.01.005 